\title{
Salinity tolerance of halophyte Atriplex nummularia L. grown under increasing $\mathrm{NaCl}$ levels
}

\author{
Sandro A.M. de Araúujo ${ }^{1}$, Joaquim A.G. Silveira', Tânia D. Almeidaa ${ }^{1}$, Iza M.A. Rocha ${ }^{1}$, Déborah L. Morais ${ }^{2} \&$ Ricardo A. Viégas $^{2}$
}

\begin{abstract}
The current study reports effects of salt stress on growth, $\mathrm{K}^{+}$nutrition and organic composition of Atriplex nummularia. The upper limit of the $\mathrm{NaCl}$ gradient imposed on the plants was close to seawater salinity $(600 \mathrm{mM})$. An external $\mathrm{NaCl}$ of $150 \mathrm{mM}$ improved the growth of this species, which corroborates its halophytic nature. Evidence show that Atriplex nummularia was responsive to $\mathrm{NaCl}$, but the mechanisms of this response are still not known. In such stress condition, $\mathrm{Na}^{+}$and $\mathrm{Cl}^{-}$accumulation in leaves was far greater than that in roots; therefore salinity tolerance of Atriplex nummularia is not due to ion exclusion mechanism. In spite of a reduction of $\mathrm{K}^{+}$content of tissues under salinity conditions, no corresponding physiological relevance of this in terms of growth was found. The high affinity of root cells for $\mathrm{Na}^{+}$during uptake and, probably, its subsequent sequestration into cell vacuoles and structures of protection seems to contribute to osmotic adjustment as an increase in relative water content (RWC) of leaves was observed. $\mathrm{NaCl}$ caused a decrease in total soluble proteins and chlorophylls; the relevance of this is discussed in terms of mechanisms of salinity tolerance. The ability of Atriplex nummularia plants to keep $\mathrm{Na}^{+}$and $\mathrm{Cl}^{-}$away from enzymes and cytosolic structures, together with an effective osmotic adjustment, is suggested as having a role in its tolerance to high salinity.
\end{abstract}

Palavras-chave: glycophytes, salinity stress, ionic imbalance

\section{Tolerância à salinidade da halófita Atriplex nummularia L. cultivada em níveis crescentes de $\mathrm{NaCl}$}

\begin{abstract}
RESUMO
O presente estudo relata os efeitos do estresse salino no crescimento, na nutrição de $\mathrm{K}^{+}$e na composição orgânica de Atriplex nummularia. A maior concentração de $\mathrm{NaCl}$ imposta às plantas foi similar a da salinidade da água do mar (600 mM). Uma concentração externa de $150 \mathrm{mM}$ de $\mathrm{NaCl}$ estimulou o crescimento da espécie o que, em parte, explica seu caráter halofítico. As evidências mostram que a Atriplex nummularia foi receptiva ao $\mathrm{NaCl}$, porém os mecanismos envolvidos são ainda esperados. Em tais condições de estresse a acumulação de $\mathrm{Na}^{+}$e $\mathrm{Cl}^{-}$nas folhas foi superior à das raízes, mostrando que a tolerância à salinidade da Atriplex nummularia não é devida ao mecanismo de exclusão de íons. Apesar do conteúdo de $\mathrm{K}^{+}$nos tecidos ter sido reduzido pela salinidade, nenhuma relevância fisiológica deste fato foi observada em termos de crescimento das plantas. A alta afinidade das raízes por $\mathrm{Na}^{+}$durante a absorção e, provavelmente, seu subseqüente seqüestro em células do vacúolo e estruturas de proteção, parece ter contribuído no ajustamento osmótico, como atesta o aumento observado no conteúdo relativo de água das folhas (RWC). $\mathrm{O} \mathrm{NaCl}$ causou decréscimo nas proteínas totais e clorofilas, cuja relevância é discutida em termos de mecanismos de resistência à salinidade. A habilidade da Atriplex nummularia em manter $\mathrm{Na}^{+}$e $\mathrm{Cl}^{-}$ longe das enzimas e das estruturas citosólicas, associada a um efetivo ajustamento osmótico, é sugerida por apresentar importante papel em sua tolerância à salinidade.
\end{abstract}

Key words: glicófitas, estresse lino, desequilíbrio iônico

DBBM/UFC, CEP-60090-170. Fortaleza, CE, Fone: (85)-4008-9821. E-mail: santriplex@yahoo.com.br; taniadiasalmeida@yahoo.com.br; izarocha2004@yahoo.com.br

2 UAEF/UFCG, PB, CEP-58700-000, Patos. Fone: (83)-3421-3397. E-mail: deborahflorest@yahoo.com.br; raviegas@uol.com.br 


\section{INTRODUCTION}

Soil salinity is the major environmental stress and largely causes yield losses of crops worldwide. This problem is more acute in arid and semi-arid regions (Munns, 2002), where salinity strongly limits crop development (Viégas et al., 2001). Salinity can inhibit plant growth due to various factors, including ion toxicity, impairment of mineral nutrition and changes in the water relations. The extent to which each of these factors can affect growth depends on plant genotype and on environmental conditions (Munns, 2002). The major saline ions, $\mathrm{Na}^{+}$and $\mathrm{Cl}^{-}$, can suppress net nutrient uptake due to competitive ionic interactions or affect membrane integrity. For example, high levels of $\mathrm{Na}^{+}$often induce $\mathrm{K}^{+}$deficiencies (Kinraide, 1999; Tester \& Davenport, 2003). Salinity may cause two kinds of stress in plant tissues: osmotic and ionic. The latter is often associated with high $\mathrm{Na}^{+} / \mathrm{K}^{+}$and $\mathrm{Na}^{+} / \mathrm{Ca}^{+2}$ ratios and accumulation of $\mathrm{Na}^{+}$and $\mathrm{Cl}^{-}$in tissues, which is harmful to general metabolism of cells (Blumwald et al., 2000). Under salt stress, maintenance of cytosolic $\mathrm{K}^{+}$and homeostasis of intracellular ion concentration is even more crucial, as emphasized by Zhu (2003).

Salinity tolerance is defined as the ability of plants to continuously grow under salt stress conditions (Munns, 2002). This makes the uptake mechanisms and accumulation pattern of ions in different plant organs important factors to determine salt tolerance (Ashraf \& Ahmad, 2000). Another major factor of salt tolerance mechanisms is the ability of plant cells to adjust osmotically and to accumulate organic solutes (proteins, sugar, amino acids, etc.). The accumulation of these compounds is not only important for cell osmo-regulation but also for the protection of subcellular structures (Munns, 2002) and maintenance of protein structures (Silveira et al., 2001).

To understand aspects of the salt tolerance, physiology of halophyte plants is important to help solve the problem of salinity in agricultural and horticultural soils. In this way, Atriplex nummularia L., a halophyte salt includer species, is particularly well adapted to arid, semi-arid and salt-affected areas (Bajji et al., 1998). In this species, salinity tolerance is often associated with the presence of avoid structures (vesiculated hairs) covering leaf surface and containing a large amount of salts (Mozafar \& Goodin, 1970). Thus, the objectives of this study were to identify cellular components and the metabolic process involved with the salt tolerance of Atriplex nummularia as related to the accumulation of organic and inorganic solutes at whole plant level.

\section{MATERIAL AND METHODS}

\section{Experimental conditions}

The study was carried out at Fortaleza/Brazil through January to March 2005, when rainy days and high air relative humidity are often observed. The plants were grown in a greenhouse on $28 / 25^{\circ} \mathrm{C}$ day/night temperatures, $55-80 \%$ relative humidity of air, mean of maximum photon flux density at plant canopy of $500 \mathrm{mmol} \mathrm{m}^{-2} \mathrm{~s}^{-1}$ (measured with a quantum sen- sor, Li-Cor, Lincoln, NE, USA) and 12 hour day length. The experiment was a completely randomized design with 4 replications, each one consisting of 1 plant per pot. Analysis of regression was performed on all data.

\section{Plant material}

The Atriplex nummularia plants were propagated by grafting from a source plant. Polyethylene bags $(20 \times 20 \times 20 \mathrm{~cm})$ filled with $2 \mathrm{~kg}$ of sandy soil were employed as plant-growing containers in the plant propagation phase. The bags were put in a fairly well illuminated place, and manual watering of bags was done once a day with excess volume of water with electrical conductivity (EC) of $0.2 \mathrm{dS} \mathrm{m}^{-1}$.

\section{Growth media}

The growth media (substrate) consisted of a mix made by 2 parts of the same soil material utilized for plant propagation and 3 parts of a soil material collected from the upper layer $(20 \mathrm{~cm})$ of a quartz sand soil. In preparing the substrate it was mixed thoroughly to make it uniform, and then put through a $2 \mathrm{~mm}$ diameter sieve to eliminate large particles. The chemical characterization of the mix is the following: $\mathrm{Ca}^{+2}, 1.20 ; \mathrm{Mg}^{+2}$, $0.50 ; \mathrm{Na}^{+}, 0.02 ; \mathrm{K}^{+}, 0.04 \mathrm{cmol}_{\mathrm{c}} \mathrm{kg}^{-1}$ soil, $\mathrm{P} 0.45 \mathrm{mg} \mathrm{kg}^{-1}$; and total $\mathrm{N}, 0.45 \mathrm{~g} \mathrm{~kg}^{-1}$. The physical soil characteristic is: sand (920), clay (40) and silt $\left(40 \mathrm{~g} \mathrm{~kg}^{-1}\right)$.

\section{Transplant and plant growth}

The resulting mixture of growth media was thoroughly washed with running water to remove excess of soluble salts before treatments were initiated. Atriplex nummularia plants (41-days-old) were placed in ceramic pots $(30 \times 30 \times 30 \mathrm{~cm})$ filled with $5 \mathrm{~kg}$ of the mixture. Irrigation was with one-half strength Hoagland solution and with distilled water on alternated days for acclimatization, during 30 days. The moisture content of the substrate was kept close of its water holding capacity during the acclimatization phase. At the end of the acclimatization phase a homogeneous group (in height) of 24 plants was selected to initiate $\mathrm{NaCl}$ treatments. The treatments consisted of four levels of $\mathrm{NaCl}$ salt $(150,300,450$ and 600 mmol L-1) dissolved in one-half strength Hoagland solution. The plants irrigated with distilled water were taken as the experimental control. The plants were irrigated every two days with $250 \mathrm{~mL}$ per pot. Once a week, the pots received a large volume (1000 mL per pot) of Hoagland nutrient solution containing no $\mathrm{NaCl}$ as a means to avoid accumulation of salt ions around roots.

\section{Plant harvest}

The plants were harvested after 7 weeks of treatment. Root, stem and leaf tissues were harvested separately. Before the harvest, samples of integral leaf tissue were collected and their relative water content were determined. The plant parts after weighing were either frozen in $\mathrm{N}_{2}$ for lyophylization or dried at $80{ }^{\circ} \mathrm{C}$ until constant dry mass (DM). The obtained material was finely ground, properly stored and further analyzed for its mineral and organic composition.

\section{Analysis of inorganic and organic solutes}

R. Bras. Eng. Agríc. Ambiental, v.10, n.4, p.848-854, 2006. 
The dried plant material was subjected to wetted digestion with a 4:1 (v/v) nitric-perchloric acid mixture; $\mathrm{Na}^{+}$and $\mathrm{K}^{+}$ were determined in the extract by flame photometry (Viégas et al., 2001). $\mathrm{Cl}^{-}$was extracted with distilled water and measured by titration against $\mathrm{AgNO}_{3}$ (Silveira et al., 2003). Chlorophylls of leaf-lyophilized tissue sample were extracted with $80 \%$ acetone and determined by Arnon (1949) method. Lyophilized stem and leaf tissues were analyzed for total $\mathrm{N}$ by Baethgen \& Allen (1979) method and total protein content was estimated using a multiplication factor of 6.25 .

\section{Relative water content and transpiration determinations}

The leaf relative water content (RWC) was determined as previously described (Silveira et al., 2001). Thirty leaf discs (diameter $1.0 \mathrm{~cm}$ ) were sampled, immediately weighed (fresh weight, FW). They were then immersed in distilled water in Petri dishes for 7 hours at $25^{\circ} \mathrm{C}$ under a photon flux density of $40 \mathrm{mmol} \mathrm{m} \mathrm{m}^{-2} \mathrm{~s}^{-1}$, blotted on a filter paper and the turgid weight (TW) determined. The discs were dried in an oven at $80{ }^{\circ} \mathrm{C}$ for 48 hours and the dry weight (DW) was obtained. RWC was calculated using the equation: $\mathrm{RWC}=[(\mathrm{FW}-\mathrm{DW})$ / (TW - DW)] x 100. The daily transpiration of plants was determined by the gravimetric method (Viégas et al., 2001) and the results were expressed as $\mathrm{mg} \mathrm{H}_{2} \mathrm{O}$ leaf $\mathrm{cm}^{-2} \mathrm{~d}^{-1}$.

\section{RESULTS AND DISCUSSION}

Salt stress induced modifications in dry mass (DM) were more pronounced in the leaves than in the roots of the plants (Figure 1A). The leaf DM gain of plants was stimulated up to $300 \mathrm{mM} \mathrm{NaCl}$ then reduced significantly $(\mathrm{P}<0.01)$ in the highest $\mathrm{NaCl}$ treatment. In $600 \mathrm{mM} \mathrm{NaCl}$ leaf DM decreased 26\% (in relation to control), while root growth was not affected $(\mathrm{P}>0.01)$ by salinity. In constrast, leaf $\mathrm{DM}$ in $300 \mathrm{mM} \mathrm{NaCl}$ was about $22 \%$ greater than in control. The fact that root DM of Atriplex nummularia was practically unaffected is reported for others species of plants (Salim, 1989, Silveira et al., 2003) and according to Bajji et al. (1998) the cellular basis of this is not yet known, since roots are the primary site of contact between plant and external salinity. Yet, stimulation as well as growth reduction due to salinity is reported in the literature for a number of glycophytic and halophytic species (Viégas et al., 2004). However, within each of these physiotype groups of plants exists a large variation among species within a genus, and of genotypes within a species, in the threshold concentration of $\mathrm{NaCl}$ that limits growth. In addition, within the halophyte physiotype group the strategy to avoid salt injury in tissues and organs largely differs. In the case of Atriplex nummularia plants there is no expenditure of energy for active transport of $\mathrm{Na}^{+}$back to the outside solution. Instead they have glands into the surface of the leaves where the salt crystallizes and, therefore, is no longer harmful (Taiz \& Zeiger, 1991). Yet, halophyte appears to have tonoplast antiporters specific for $\mathrm{Na}^{+}$that enable the cell to sequester $\mathrm{Na}^{+}$inside the vacuoles and thus avoid its toxicity in the cell cytoplasm (Blumwald \& Poole, 1985).
A.

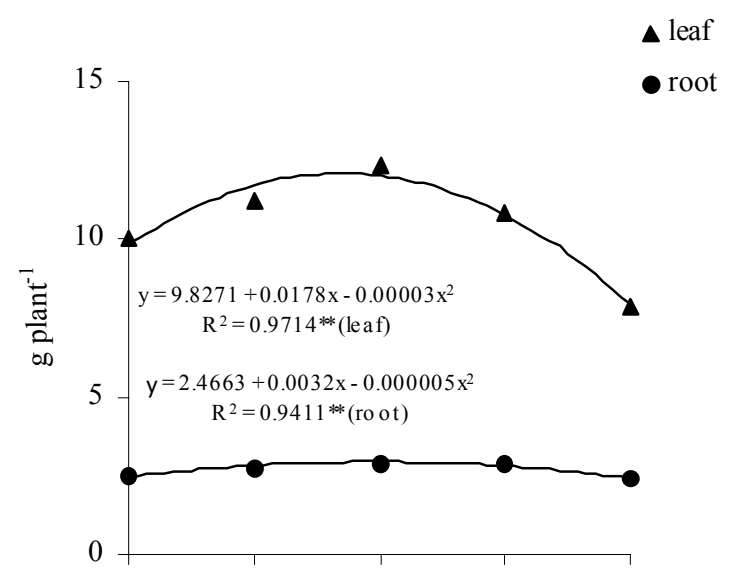

B.

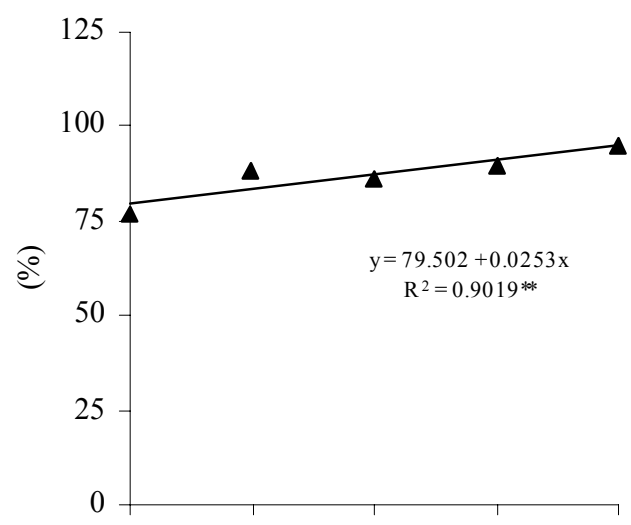

C.

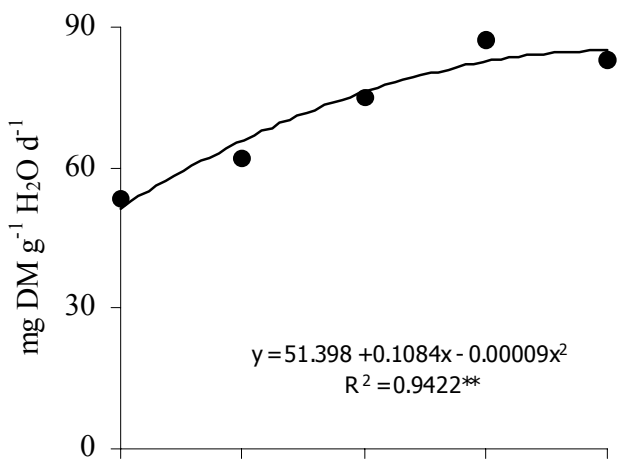

D.

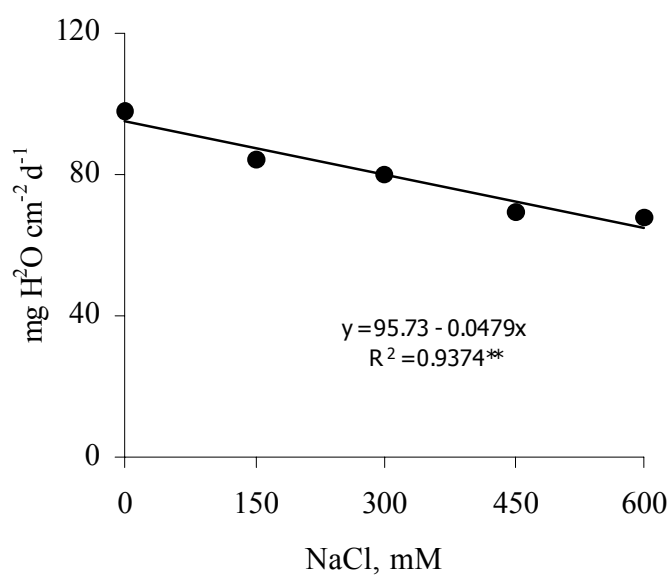

Figure 1. Dry matter in root and leaf (A), relative water content (RWC) in leaf (B), water use efficiency at whole plant level (C) and transpiration rates (D) in Atriplex nummularia plants grown in a media artificially salinized with $\mathrm{NaCl}$. ** Significant at 0.01 probability (F test) 
In spite of transpiration rates of Atriplex plants having decreased rapidly with increasing external salinity (Figure 1D), the leaf relative water content increased steadily to be significantly higher in $600 \mathrm{mM} \mathrm{NaCl}$ (Figure 1B). It appears that these processes do not depend on each other, at least under salt stress conditions. In addition, it could be stated that growth of Atriplex nummularia under salinity is not dependent either on tissue water or on transpiration. Note that growth (in terms of DM gain) of leaves was strongly reduced in the $\mathrm{NaCl}$ range of 300 to $600 \mathrm{mM}$, whereas RWC of that organ was about $22 \%(\mathrm{P}<0.01)$ more than the control. This increased leaf succulence is likely to be because the salt concentration gradient of cell cytosol and organelles became steeper and make the cell cytosol adjust osmotically (Silveira et al., 2003). However, in the same range of $\mathrm{NaCl}$ (300 to $600 \mathrm{mM}$ $\mathrm{NaCl}$ ), DM accumulation of the leaves was strongly reduced (Figure 1) ensuring that cell turgor is not a limiting factor for the growth of Atriplex plants under high salinity.

The ability of Atriplex to keep leaf RWC at a level above the control, despite high external salinity and associated metabolic implication of this, makes it less vulnerable to the osmotic and ionic stress caused by salinity. This, at least partly, may help alleviate the impact of excess accumulation of $\mathrm{Na}^{+}$ and $\mathrm{Cl}^{-}$in tissues and probably gives rise to some metabolic traits that enable Atriplex to use water more efficiently (Figure 1C), even in $\mathrm{NaCl}$ concentrations inhospitable for most terrestrial plant species. Therefore, the assumption is that the weights of carbon dioxide assimilated/water transpired of Atriplex plants increased with increasing external salinity concentration. In the plants with $\mathrm{C}_{4}-\mathrm{CO}_{2}$ fixing system the activity of phosphoenolpyruvate carboxylase (the primary carboxilating enzyme) is increased by $\mathrm{Na}^{+}$, as it is the case of Atriplex genus.

The high affinity of Atriplex nummularia roots for $\mathrm{Na}^{+}$ makes the uptake and accumulation of this ion in the leaves a very effective process (Figure 2A,C). For this reason, this plant is classified as a salt includer physiotype and therefore it does not prevent potential harmful ions from reaching photosynthetic tissues. A more thorough view of this is that $\mathrm{Na}^{+}$ has concentrated far in excess in the leaf (by $2.0 \mathrm{~mol} \mathrm{~kg}^{-1} \mathrm{DM}$ ) compared to Atriplex plants grown under physiological (control) conditions (Figure 2A). A more probable explanation of this is that Atriplex nummularia plants have too low $\mathrm{km}$ values for $\mathrm{Na}^{+}$during uptake. Note that the substrate in which Atriplex nummularia grew was very poor for exchangeable ions, mainly $\mathrm{Na}^{+}$(see Material and Methods), and that most of the plant species, especially glycophytes, are intolerant of only $1 / 5$ of control $\mathrm{Na}^{+}$leaf concentration. Yet, in succulent halophytes, such as Suaeda maritima, $\mathrm{Na}^{+}$uptake by roots is 10 times greater than $\mathrm{K}^{+}$uptake and is probably too rapid for known carrier-transport processes (Edward \& Brown, 1999). Comparison of the $\mathrm{Na}^{+}$concentrations in the leaf, stem and roots point out leaves to be the main site of $\mathrm{Na}^{+}$ accumulation in the Atriplex plants (Figure 2A, B, C). While interesting, this had some physiological and biochemical relevance for the growth of Atriplex in a given range of $\mathrm{NaCl}$ (up to $300 \mathrm{mM}$ ).
A.

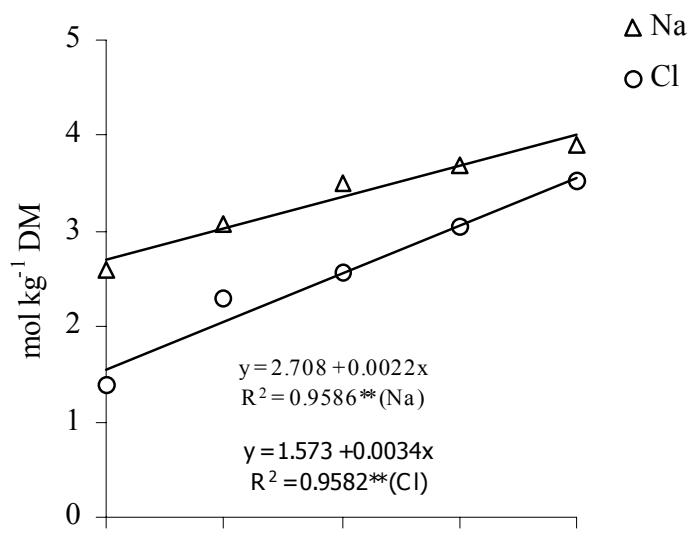

B.

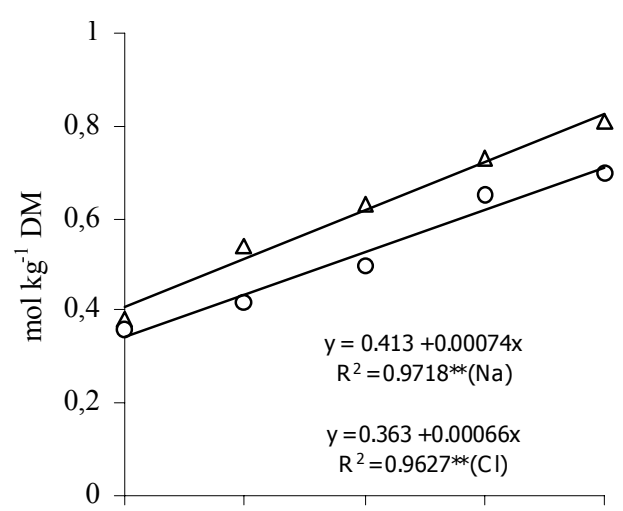

C.

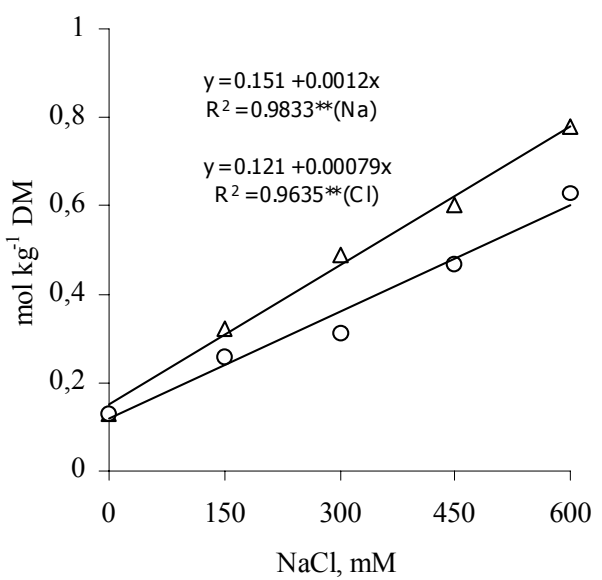

Figure 2. $\mathrm{Na}^{+}$and $\mathrm{Cl}^{-}$concentration in leaf (A), stem (B) and root (C) tissues of Atriplex nummularia plants grown in a media artificially salinized with $\mathrm{NaCl}$. ** Significant at 0.01 probability ( $\mathrm{F}$ test)

Atriplex appears to be particularly responsive to $\mathrm{Na}^{+}$, and the possibility that $\mathrm{Na}^{+}$is required for its growth should be considered. Comparative studies within a genus, or of genotypes within a species, have shown that halophyte salt tolerance can be positively correlated with capacity for $\mathrm{Na}^{+}$uptake into the shoot tissues (leaf and stem) (Erdei \& Kuiper, 1979; Glenn et al., 1997). Although growth rate had differed among genotype of glycophytes plants, it was strongly correlated with capacity for $\mathrm{Na}^{+}$vacuolar accumulation and negatively correlated with capacity for $\mathrm{K}^{+}$uptake (Glenn et al., 1996). According to Amtmann \& Maathuis (1999), $\mathrm{Na}^{+}$is only essential in a number of C4-species for the translocation of 
pyruvate across the chloroplast envelop, where it functions as a micronutrient. In most species, $\mathrm{Na}^{+}$does not act as a nutrient, in the sense that it is not strictly required for growth. However, its addition to the growth medium may promote growth of many plants where $\mathrm{K}^{+}$supply is limited (Martínez-Ballesta et al., 2004) and, in particular, to the growth of salt tolerant and halophytic plant species by contributing to its turgor formation (Mansour \& Salama, 2004).

For Atriplex it seems that $\mathrm{Na}^{+}$depletion from xylem as this ion moves upward, and its circulation via phloem, is a very restricted processThus, Atriplex has no endogenous control mechanism to avoid leaf biochemical machinery for excess accumulation of $\mathrm{Na}^{+}$and as well $\mathrm{Cl}^{-}$, either by moving these ions back outside the plant (reducing net uptake) or to storing them in other organs such as roots and/or stems. In addition, since enzymes of glycophytes are (in vitro) as sensitive as halophytes to salinity (Silveira et al., 2001), then Atriplex protects its subcellular structures through an efficient mechanism of salt ions compartmentalization in vacuoles and other structures as well. Yet, Atriplex nummularia takes up $\mathrm{Na}^{+}$and $\mathrm{Cl}^{-}$in high amounts but seems to store them efficiently up to an external $300 \mathrm{mM} \mathrm{NaCl}$ level only. Above this concentration, however, such mechanism fails and growth of shoot tissues is negatively affected. Thus, at greater than external $300 \mathrm{mM} \mathrm{NaCl}$ levels Atriplex is not as efficient at compartmentalizing salt ions as at lower concentrations. It could be stated that a maximum cell capability to store $\mathrm{Na}^{+}$in leaf (in vacuoles and other structures) without depressing growth of Atriplex is around $2.5 \mathrm{~mol} \mathrm{~kg}^{-1} \mathrm{DM}$ and for $\mathrm{Cl}^{-}$it is around $3.5 \mathrm{~mol} \mathrm{~kg}^{-1} \mathrm{DM}$. There is then the consideration that salinity stress that Atriplex plants deal with lasted for over 49 days, a time length enough to reinforce the above discussed. Although high amount of $\mathrm{Na}^{+}$is accumulated outside of the Atriplex leaf in vesiculated hairs (avoid structures), this protective mechanism does not alone explain the stimulation of growth recorded in the present study. Such an assumption agrees with that of Bajji et al. (1998) who studied Atriplex halimus grown in a medium artificially salinized with $\mathrm{NaCl}$. These authors also reported that the physiological mechanisms underlying growth stimulation of Atriplex plants are still unknown and that such genus undoubtedly constitutes one of the more convenient subjects for investigating the halophytic properties in the plant kingdom.

Although not proven, assumptions exist toward increased activity of protein synthesis (that leads to growth improvement and is considered of great biochemical and physiological relevance) within a given range of $\mathrm{NaCl}$ depending on plant species. More recently Viégas et al. (2004) have reported growth stimulation of salinized Prosopis juliflora in $50 \mathrm{mM}$ $\mathrm{NaCl}$ (although harmful at $75 \mathrm{mM}$ ) only after total $\mathrm{N}$ (total proteins) of leaf increased.

By increasing $\mathrm{NaCl}$ concentrations around roots of Atriplex the regression lines for $\mathrm{Na}^{+}$and $\mathrm{Cl}^{-}$accumulation had a very similar tendency in leaf, stem and root (Figure 2A, B, C). There seems to be coordination between $\mathrm{Na}^{+}$and $\mathrm{Cl}^{-}$accumulation, suggesting a higher level integrating mechanism between uptake systems of these two ions as $\mathrm{NaCl}$ concen- tration around roots increases. Apparently, both uptake systems of Atriplex nummularia seem to be regulated with each other. Evidences show that under physiological condition (control) $\mathrm{Na}^{+}$(Maathius et al., 1992) and $\mathrm{Cl}^{-}$(Martínez-Ballesta et al., 2004) ions are actively transported outward across the plasma membrane, implying it to be independent process (not regulated). On the contrary, by increasing external $\mathrm{NaCl}$ the uptake of $\mathrm{Na}^{+}$occurs with no energy expenditure (downhill). This is due to large inside negative $\ddot{A} \varnothing$ of cytoplasm with respect to the apoplast (Schachtman et al., 1991). In turn, this will cause depolarizing $\ddot{A} \varnothing$ across plasma membranes (Niu et al., 1995), a condition under which $\mathrm{Cl}^{-}$uptake is also expected to be downhill through outward rectifying channels (Skerrtt \& Tyerman, 1994).

Atriplex nummularia may use the controlled uptake of $\mathrm{Na}^{+}$ (balanced by other ions, specially $\mathrm{Cl}^{-}$) into cells to drive water into the plant against low external water potential (Blumwald et al., 2000), thereby preserving homeostasis of intracellular ion concentrations which is fundamental to the physiology of living cells (Zhu, 2003). Under these conditions, proper compartmentalization is needed to keep toxic ions concentrations low in the cytosol and to accumulate essential ions. In addition, once leaf RWC increased, osmotic adjustment in Atriplex nummularia appears to be very effective. Thus, $\mathrm{Na}^{+}$and also $\mathrm{Cl}^{-}$may partly account for the decrease in cell $\varnothing$ together with other organic compounds such as proline, sugars and glycinbetaine (Silveira et al., 2001).

Salinity has contributed to reduce $\mathrm{K}^{+}$content of plants more markedly in root than in leaf of Atriplex (Figure 3A). The leaf $\mathrm{K}^{+}$content of plants in $600 \mathrm{mM} \mathrm{NaCl}$ (seawater salinity) represented about $78 \%$ that of control, while that of root is about $60 \%$. This may be the expression of metabolic disorders and shows how greatly uptake and $\mathrm{K}^{+}$discharge into xylem differed in Atriplex as a result of imposed salt stress. Many researchers have observed that salinity reduces the $\mathrm{K}^{+}$accumulation of salt stressed plants, and this is usually attributed to the competition of $\mathrm{K}^{+}$and $\mathrm{Na}^{+}$during uptake (reducing $\mathrm{K}^{+}$influx) and returning back of $\mathrm{K}^{+}$to the bathing solution (increasing $\mathrm{K}^{+}$efflux), mostly due to induced plasma membrane integrity losses (Silveira et al., 2003). Each of these factors alone, or in combination, may strongly reduce net uptake of the $\mathrm{K}^{+}$nutrient.

In the gradient of external salinity utilized, the responses of Atriplex nummularia for solutes accumulation at leaf and root level did not differ; the concentration of $\mathrm{Na}^{+}$and $\mathrm{Cl}^{-}$increased (Figure 2A, B) while that of $\mathrm{K}^{+}$, chlorophylls and total proteins decreased (Figure 3A, B, C). This is an indication that the metabolic events associated to the control mechanism that allows plants to survive the imposed salt stress are the same in the presence of both low $(150 \mathrm{mM})$ and high $(600$ $\mathrm{mM}$ ) NaCl-salinity. In other words, Atriplex nummularia plants behaved as a salt includer species independently of $\mathrm{NaCl}$ dose. In the work by Bajji et al. (1998), another species (halimus) of the genus Atriplex adopted two different strategies - it behaved as salt includer at low salinity and as excluder at high. Interestly, both of these Atriplex (nummularia and halimus) species had stimulated growth in the range of $\mathrm{NaCl}$ from 150 to $300 \mathrm{mM}$. 
A.

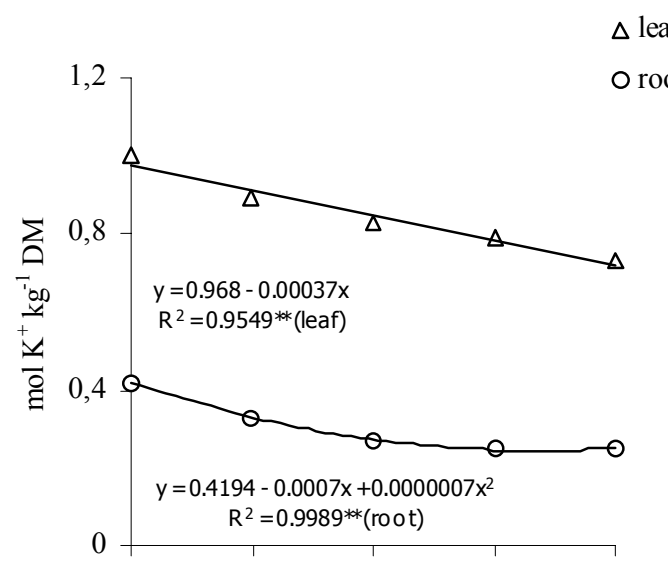

B.

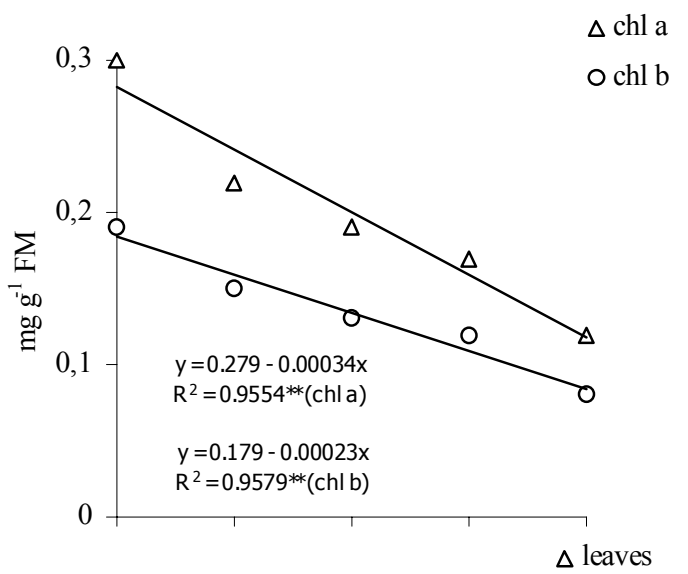

C.

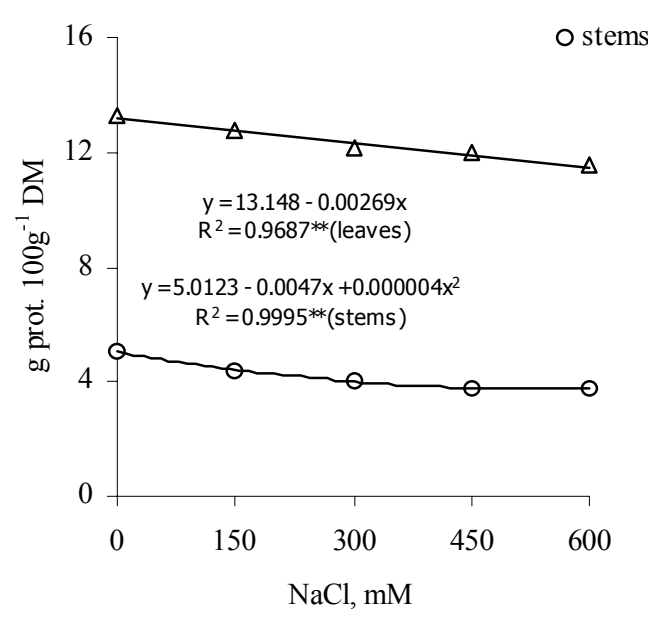

Figure 3. $\mathrm{K}^{+}(\mathrm{A})$, chlorophylls (B) and total proteins (C) concentrations in the Atriplex nummularia plants grown in a media artificially salinized with $\mathrm{NaCl}$. ** Significant at 0.01 probability (F test)

The leaf growth stimulation of Atriplex up to $300 \mathrm{mM} \mathrm{NaCl}$ (Figure 1A) was associated with a reduction in content of leaf chlorophylls (Figure 3B). Although this seems to be a very contradictory result, it is not, because the determination of the organic composition was done for the primary basal oldest leaves. This is where increased proteolysis activity occurred and symptoms of early senescence (chlorosis and necrotic areas) were observed. To date, an increase in activity of leaf proteases is often associated with a reduction in contents of total proteins and chlorophylls (Figure 3B,C) and frequently causes solute export from the oldest (there including photosynthetic apparatus) to the youngest leaves. Growth stimulation depends on a rigid coordination of metabolic functions to face the limiting growth conditions due to salinity. Above $300 \mathrm{mM} \mathrm{NaCl}$, it appears that the metabolic coordination (homoeostasis breakdown) of Atriplex nuтmularia fails, a salinity concentration in which its growth starts to reduce.

\section{CONCLUSIONS}

1. The Atriplex nummularia plant responses to salinity, in terms of leaf dry mass production, changing from stimulation up to $300 \mathrm{mM} \mathrm{NaCl}$ to reduction at higher levels.

2. Atriplex nummularia plant has no exclusion mechanism at root level to avoid excess accumulation of salt ions in leaves and therefore it is a salt includer species.

3. Increase in leaf relative water centent with increasing salinity indicates that Atriplex nummularia plants seem to have an efficient mechanism to adjust cell cytosol osmotically. Thus leaf turgor is not a limiting factor for growth.

4. Atriplex nummularia has a great affinity for $\mathrm{Na}^{+}$and $\mathrm{Cl}^{-}$ ions during uptake. This is confirmed through the substantial accumulation of these ions in tissues under physiological conditions (control), and the fact that salt ions are concentrated in leaf rather than in root tissue, regardless of $\mathrm{NaCl}$ dose.

\section{ACKNOWLEDGMENTS}

The authors wish to thank the CNPq and FUNCAP for a research grant in support of this research.

\section{LITERATURE CITED}

Amtmann, A.; Maathuis, F.J.M. $\mathrm{K}^{+}$Nutrition and $\mathrm{Na}^{+}$toxicity: The basis of cellular $\mathrm{K}^{+} / \mathrm{Na}^{+}$Ratios. Annals of Botany, London, v.84, n.2, p.123-133, 1999.

Arnon, D.I. Copper enzymes in isolated chloroplast polyphenoloxidases in Beta vulgaris. Plant Physiology, Rockville, v.24, n.1, p.1-15, 1949.

Ashraf, M.; Ahmad, S. Influence of sodium on ion accumulation, yield components and fibre characteristics in salt-tolerant and salt-sensitive lines of cotton (Gossypium hirsutum L.). Field Crops Research, Phoenix, v.66, n.2, p.115-127, 2000.

Baethgen, W.E.; Allan, M.M. A manual of colorimetric procedures for measuring ammonium nitrogen in soil and plant. Community Soil Science and Plant Annals, Illinois, v.20, n.9/10, p.961-969, 1979.

Bajji, M.; Kinet, J.M.; Lutts, S. Salt stress effects on roots and leaves of Atriples halimus L. and their corresponding callus cultures. Plant Science, Berlin, v.137, n.2, p.131-142, 1998.

R. Bras. Eng. Agríc. Ambiental, v.10, n.4, p.848-854, 2006. 
Blumwald, E., Aharon, G.S., Apse, M.P. Sodium transport in plant cells. Biochemistry Biophysical Acta, London, v.1465, n.1, p.140-151, 2000.

Blumwald, E.; Poole, R. Na/H-antiportin isolated tonoplast vesicles from storage tissue of Beta vulgaris. Plant Physiology, Rockville, v.78, n.1, p.163-167, 1985.

Edward, P. G.; Brown, J. J. Salt tolerance and crop potential of halophytes. Plant Science, Berlin, v.138, n.2, p.227-253, 1999.

Erdei, L.; Kuiper, P.. The effect of salinity on growth, cation content, $\mathrm{Na}$ uptake and translocation in salt-sensitive and salt-tolerant Plantago species. Plant Physiology, Rockville, v.47, n.1, p.95-99, 1979.

Glenn, E.; Miyamoto, M.; Moore, D.; Brown, J.J.; Thompson, T.L.; Brown, P. Water requirements for cultivating Salicornia bigelovii Torr. on sand in a coastal desert environment. Journal on Arid Environment, Tucson, v.36, n.3, p.711-730,1997.

Glenn, E.P.; Pfister, R.; Browa, J.; Thompson, T.L.; O’Leary, J. $\mathrm{Na}$ and $\mathrm{K}$ accumulation and salt tolerance of Atriplex canescens (Chenopodiacea) genotypes. American Journal of Botany, New York, v.83, n.3, p.997-1005, 1996.

Kinraide, T. B. Interactions among $\mathrm{Ca}^{+2}, \mathrm{Na}^{+}$and $\mathrm{K}^{+}$in salinity toxicity: quantitative resolution of multiple toxic and ameliorative effects. Journal of Experimental Botany, Oxford, v.50, n.3, p.1495-1505, 1999.

Maathius, F. J. M.; Flowers, T. J.; Yeo, A.R. Sodium chloride compartimentation in leaf vacuoles of the halophyte $\mathrm{Su}$ aeda maritime (L.) Dum and its relation to tonoplast permeability. Journal of Experimental Botany, Oxford, v.43, n.2, p.1219-1223, 1992.

Mansour, M.M.; Salama, K.H.A. Cellular basis of salinity tolerance in plants. Environmental and Experimental Botany, Memphis, v. 52, n.2, p. 113-122, 2004.

Martínez-Ballesta, M. C.; Martínez, V.; Carvajal, M. Osmotic adjustment, water relations and gás exchange in pepper plants grown under $\mathrm{NaCl}$ or $\mathrm{KCl}$. Environmental and Experimental Botany, Memphis, v.52, n.2, p.161-174, 2004.

Mozafar, A.; Goodin, J.R. Vesiculated hairs: a mechanism for salt tolerance in Ariplex halimus L. Plant Physiology, Rockville, v.45, n.1, p.62-65, 1970.

Munns, R. Comparative physiology of salt and water stress. Plant Cell Environment, Logan, v.25, n.5, p.659-662, 2002.
Niu, X.; Bressan, R. A.; Hasegawa, P. M. Pardo, J. M. Ion homoeostasis in $\mathrm{NaCl}$ stress environments. Plant Physiology, Rockville, v.109, n.3, p.735-742, 1995.

Salim, M. Effects of salinity and relative humidity on growth and ionic relations of plants. New Phytology, Baltimore, v.113, n.1, p.13-20, 1989.

Schachtman, D.; Tyerman, T.; Terry, B. The K/Na selectivity of a cation channel in the plasma membrane of root cells does not differ in salt-tolerant and salt-sensitive wheat species. Plant Physiology, Rockville, v.97, n.2, p.598-605, 1991.

Silveira J.A.G.; Melo A.R.B.; Viégas R.A.; Oliveira, J.T.A. Salinity-induced effects on nitrogen assimilation related to growth in cowpea plants. Environmental and Experimental Botany, Memphis, v.46, n.2, p.171-179, 2001.

Silveira, J.A.G., Viégas, R.A., Rocha, I.M.A., Moreira, A.C.O.M., Moreira, R.A., Oliveira, J.T.A. Proline accumulation and glutamine synthetase activity are increased by salt induced proteolysis in cashew leaves. Journal of Plant Physiology, Cordoba, v.160, n.2, p.115-123, 2003.

Skerrtt, M.; Tyerman, S.D. A channel that allows inwardly directed fluxes of anions in protoplast derived from wheat roots. Planta, Berlin, v.192, n.2, p.295-305, 1994.

Taiz, L.; Zeiger, E. Plant physiology. 1 ed. Los Angeles: The Benjamin/Cumming Publishing Company, v.559, 1991, p.363

Tester, M., Davenport, R. $\mathrm{Na}^{+}$resistance and $\mathrm{Na}^{+}$transport in higher plants. Annals of Botany, Ottawa, v.91, n.3, p.503527, 2003.

Viégas, R.A.; Fausto, M.J.M.F.; Silveira, J.A.G.; Queiroz, J.E.Q. Growth and total N content of Prosopis juliflora (SW) D. C. are stimulated by mild $\mathrm{NaCl}$ level. Brazilian Journal of Plant Physiology, Campinas, v.16, n.1, p.65-68, 2004.

Viégas, R.A.; Silveira, J.A.G.; Junior, A.R.L. Effects of NaCl-salinity on growth and inorganic solute accumulation in young cashew plants. Revista Brasileira de Engenharia Agrícola e Ambiental, Campina Grande, v.5, n.2, p.216-222, 2001.

Zhu, J. Regulation of ion homeostasis under salt stress. Current Opinion in Plant Biology, Dorderecht, v.6, n.2, p.441445, 2003. 